\title{
Post-natal induction of PGC-1a protects against severe muscle dystrophy independently of utrophin
}

\author{
Mun Chun Chan, Glenn C Rowe, Srilatha Raghuram, lan S Patten, Caitlin Farrell and Zolt Arany*
}

\begin{abstract}
Background: Duchenne muscle dystrophy (DMD) afflicts 1 million boys in the US and has few effective treatments. Constitutive transgenic expression of the transcriptional coactivator peroxisome proliferator-activated receptor gamma coactivator (PGC)-1a improves skeletal muscle function in the murine "mdx" model of DMD, but how this occurs, or whether it can occur post-natally, is not known. The leading mechanistic hypotheses for the benefits conferred by PGC-1a include the induction of utrophin, a dystrophin homolog, and/or induction and stabilization of the neuromuscular junction.
\end{abstract}

Methods: The effects of transgenic overexpression of PGC-1 $\beta$, a homolog of PGC-1a in mdx mice was examined using different assays of skeletal muscle structure and function. To formally test the hypothesis that PGC-1a confers benefit in mdx mice by induction of utrophin and stabilization of neuromuscular junction, PGC-1a transgenic animals were crossed with the dystrophin utrophin double knock out $\left(\mathrm{mdx} / \mathrm{utrn}^{-/}\right)$mice, a more severe dystrophic model. Finally, we also examined the effect of post-natal induction of skeletal muscle-specific PGC-1a overexpression on muscle structure and function in mdx mice.

Results: We show here that PGC-1 $\beta$ does not induce utrophin or other neuromuscular genes when transgenically expressed in mouse skeletal muscle. Surprisingly, however, PGC-1ß transgenesis protects as efficaciously as PGC-1a against muscle degeneration in dystrophin-deficient $(\mathrm{mdx})$ mice, suggesting that alternate mechanisms of protection exist. When PGC-1a is overexpressed in $\mathrm{mdx} / \mathrm{utrn}^{-1-}$ mice, we find that PGC-1a dramatically ameliorates muscle damage even in the absence of utrophin. Finally, we also used inducible skeletal muscle-specific PGC-1a overexpression to show that PGC-1 a can protect against dystrophy even if activated post-natally, a more plausible therapeutic option.

Conclusions: These data demonstrate that PGC-1a can improve muscle dystrophy post-natally, highlighting its therapeutic potential. The data also show that PGC-1a is equally protective in the more severely affected $\mathrm{mdx}_{\mathrm{utrn}}{ }^{-1-}$ mice, which more closely recapitulates the aggressive progression of muscle damage seen in DMD patients. The data also identify PGC-1 $\beta$ as a novel potential target, equally efficacious in protecting against muscle dystrophy. Finally, the data also show that PGC-1a and PGC-1 $\beta$ protect against dystrophy independently of utrophin or of induction of the neuromuscular junction, indicating the existence of other mechanisms.

Keywords: PGC-1a, PGC-1 $\beta$, mdx, Duchenne Muscle Dystrophy, Utrophin, Neuromuscular junction

\footnotetext{
* Correspondence: zarany@bidmc.harvard.edu

Cardiovascular Institute, and Center for Vascular Biology Research, Beth Israel

Deaconess Medical Center and Harvard Medical School, 330 Brookline Ave, 02215 Boston, MA, USA
} reproduction in any medium, provided the original work is properly cited. The Creative Commons Public Domain Dedication waiver (http://creativecommons.org/publicdomain/zero/1.0/) applies to the data made available in this article, unless otherwise stated. 


\section{Background}

Duchenne muscle dystrophy (DMD) is an inexorably fatal recessive $\mathrm{X}$-linked hereditary disease that affects 1 in 3,600 boys in the US and is marked by progressive muscle dystrophy that ultimately leads to paralysis and respiratory and/or cardiac failure [1-5]. The disease is caused by mutations in the dystrophin gene, which encodes for a critical component of the dystroglycan complex (DGC) that connects the extracellular matrix of muscle fibers to the cytoskeleton $[4,6,7]$. Dysfunctional DGC leads to excess intracellular calcium, mitochondrial dysfunction, loss of sarcolemmal integrity, and ultimately cell death, but the precise pathogenesis of DMD remains unclear $[4,6,8]$. Therapeutic options for DMD remain limited, and no significant pharmacological advances have been made since the introduction of steroids in the 1970s [1-3]. A deeper understanding of protective mechanisms is needed.

Utrophin is an important component of the neuromuscular junction (NMJ) and bears significant sequence and functional homology to dystrophin $[9,10]$. Dystrophindeficient $(\mathrm{mdx})$ mice, in which the dystrophin gene is mutated, are widely used as a model of DMD, and genetic deletion of utrophin superimposed on the mdx background greatly worsens the observed dystrophy, consistent with redundant function between utrophin and dystrophin [10-15]. The dystrophin utrophin double knock-out mouse $\left(\mathrm{mdx} / \mathrm{utrn}^{-1}\right)$ models the severity of human DMD phenotype more faithfully than the parental dystrophin knock-out (mdx) mouse [11,12,15]. Conversely, transgenic expression of utrophin in skeletal muscle significantly improves indices of dystrophy in mdx mice $[3,10,16]$. Utrophin has thus been proposed as a potential therapeutic target, and efforts are underway to translate these observations to the clinical setting.

Transgenic overexpression in skeletal muscle of peroxisome proliferator-activated receptor gamma coactivator (PGC)- $1 \alpha$ has also been shown to markedly improve dystrophy in $\mathrm{mdx}$ mice [17]. PGC-1 $\alpha$ powerfully regulates broad programs of gene expression by binding to, and coactivating, numerous transcription factors [18-20]. In most tissues, including skeletal muscle, PGC- $1 \alpha$ strongly induces mitochondrial biogenesis by co-activating nuclear respiratory factor 1 (NRF1), NRF2, estrogen-related receptor $\alpha$ (ERR $\alpha)$, and other transcription factors. At the same time, PGC- $1 \alpha$ induces the expression of a number of ancillary programs, including fatty acid transport and oxidation [21-23]. PGC-1 $\beta$, a homolog that bears extensive sequence identity with $\mathrm{PGC}-1 \alpha$ in a number of functional domains, shares many, though not all, of these functions [24-28].

In skeletal muscle, PGC- $1 \alpha$ also induces genes that encode components of the neuromuscular junction $[17,29]$. NRF2, composed of a hetero-tetramer of GA-binding protein $\alpha$ chain (GABPA) and GA-binding protein $\beta$ chain (GABPB), was in fact independently identified as a key transcription factor in the regulation of NMJ genes. Consistent with this, PGC- $1 \alpha$ strongly induces utrophin expression both in cells and in mice that transgenically overexpress PGC-1 $\alpha$ in skeletal muscle $[17,29,30]$. As noted above, these same transgenic mice markedly improve dystrophy in the $\mathrm{mdx}$ background [17]. This strong protection has thus widely been ascribed to the induction of utrophin by PGC-1 $\alpha$ [17,31-34], although this has never formally been tested. It is also not clear when in development the induction of PGC-1 $\alpha$ is most critical, because prenatal changes in dystrophin-deficient muscle means that prenatal expression of PGC- $1 \alpha$ may have had important effects [35,36].

Here, we use various transgenic mice to test if induction of utrophin by PGC-1 $\alpha$ is necessary for amelioration of muscle damage in DMD models. We find that PGC- $1 \alpha$ surprisingly protects against dystrophy independently of utrophin. In fact, PGC- $1 \alpha$ efficiently protects the $\mathrm{mdx} / \mathrm{utrn}^{-1-}$ mice, which, as noted above, model the severity of human DMD more faithfully than the parental mdx mouse [15]. We also show that PGC-1 $\beta$ protects against dystrophy as efficaciously as PGC- $1 \alpha$, even though PGC-1 $\beta$ does not induce utrophin or genes of the NMJ. Finally, we use an inducible transgenic model to show that induction of PGC- $1 \alpha$ well after birth can still confer efficient protection against dystrophy, a more plausible therapeutic scenario.

\section{Methods}

\section{Animals}

All animal experiments were performed according to procedures approved by the Beth Israel Deaconess Medical Center's Institutional Animal Care and Use Committee. C57BL/10ScSn-Dmd $d^{\mathrm{mdx}} / \mathrm{J}$ mice (mdx mice) [37] and Utrn ${ }^{\text {tm1Jrs }} D m d^{m d x} / J$ mice $\left(\mathrm{mdx} / \mathrm{utrn}^{-/-}\right.$mice) $[11,13]$ were obtained from Jackson Laboratories (Bar Harbor, Maine, USA). These mice were crossed with: muscle-specific PGC- $1 \alpha$ transgenic mice (MCK-PGC- $1 \alpha$ ) [38]; musclespecific PGC-1 $\beta$ transgenic mice (MCK-PGC-1 $\beta$ ) [39]; or mice with inducible PGC-1 $\alpha$ that possess the muscle specific tetracycline-dependent activator (MCK-tTA) and the PGC- $1 \alpha$ coding region under control of the tetresponse element promoter (TRE-PGC-1 $\alpha$ ) transgenic genes (Ind_PGC-1 $\alpha$ ) [40]. $\mathrm{mdx}, \mathrm{mdx} / \mathrm{MCK}-\mathrm{PGC}-1 \alpha$, $\mathrm{mdx} / \mathrm{MCK}-\mathrm{PGC}-1 \beta$ and $\mathrm{mdx} / \mathrm{Ind} \_\mathrm{PGC}-1 \alpha$ are products of crosses between animals in the C57/BL/6J background (MCK-PGC- $1 \alpha$, MCK-PGC- $1 \beta$ and Ind_PGC- $1 \alpha$ mice) and $\mathrm{C} 57 / \mathrm{BL} / 10 \mathrm{ScSn}$ (mdx mice) background. All nondystrophic mice, including wild-type (WT) controls were in the $\mathrm{C} 57 / \mathrm{BL} / 6 \mathrm{~J}$ background. The $\mathrm{mdx} / \mathrm{utrn}^{-1-}$ mice as provided by Jackson Laboratories are in a mixed background. Therefore, all experimental groups with these mice were conducted on sibling-mates in mixed 
background. Sedentary mdx/MCK-PGC-1 $\alpha, \mathrm{mdx} / \mathrm{MCK}-$ PGC- $1 \beta$ and $\mathrm{mdx} / \mathrm{utrn}^{-/-} / \mathrm{MCK}-\mathrm{PGC}-1 \alpha$ mice were analyzed at 5 weeks of age, while exercise experiments were performed on 10-week-old mice ( $\mathrm{n}=5$ per experimental group). $\mathrm{mdx} /$ Ind_PGC- $1 \alpha$ were induced by removal of doxycycline from chow at 3 weeks of age and experiments performed at 7 weeks of age $(n=5$ per experimental group).

\section{Growth curves and radiograph}

Body weight and body length (nose to tail base) of litter mates from mdx/utrn ${ }^{+/} /$MCK-PGC- $1 \alpha$ male crossed with $\mathrm{mdx} / \mathrm{utrn}^{+/}$females was measured in a blinded fashion from 5 weeks to 15 weeks of age. Radiographs of representative animals in each genotype were taken of anesthetized animals at 13 weeks of age.

\section{Treadmill exercise}

Ten-week-old mice were run for 1 hour or until exhaustion on a treadmill at a $15^{\circ}$ downhill angle ( $1^{\text {st }}$ run). Treadmill speed was steadily increased, starting at $10 \mathrm{~m} /$ minute for 5 minutes, then increasing to $15 \mathrm{~m} /$ minute for 5 minutes, $20 \mathrm{~m} /$ minute for 5 minutes, and finally $25 \mathrm{~m} /$ minute for 45 minutes. Blood was drawn 2 hours after the run. This exercise protocol was repeated after a 24 hour resting period $\left(2^{\text {nd }}\right.$ run). Mice were sacrificed 2 hours after the $2^{\text {nd }}$ run.

\section{Cell culture}

Primary satellite cells were isolated and cultured from the entire hind limb of WT mice as previously described $[41,42]$. Cells were differentiated into myotubes using DMEM with $5 \%$ horse serum for 72 hours. Cells were then infected with control (GFP) adenovirus (WT), recombinant PGC- $1 \alpha$ adenovirus (Ad-PGC-1 $\alpha$ ) or recombinant PGC-1 $\beta$ adenovirus (Ad-PGC-1 $\beta$ ) at multiplicity of infection of 10 to 30 [43]. Cells were analyzed 48 hours later.

\section{Evans blue injection and histological analysis}

For Evans Blue assay, mice were injected with 1\% solution intraperitoneally at a final concentration of $1 \%$ volume to body weight 16 hours prior to sacrifice. Tissues were dissected and embedded in OCT compound (VWR, Radnor, Pennsylvania, USA) and flash-frozen. Evans Blue was analyzed by fluorescence microscopy. Sections were also stained with rabbit polyclonal anti-laminin antibody (Abcam, ab11575, Cambridge, Massachusetts, USA) in order to establish fiber boundaries. We used two different staining techniques in this report to calculate centralized nuclei: i) frozen sections were stained with anti-laminin and counterstained with 4',6-diamidino-2-phenylindole (DAPI); ii) tissue was dehydrated and embedded in paraffin and sectioned before hematoxylin and eosin staining.
In either case, 20 images were taken at $200 \times$ and the number of centralized nuclei to overall number of nuclei counted in a blinded fashion.

\section{Serum creatine kinase assay}

Blood was collected and serum isolated using heparincoated collection tubes, either by heart puncture or cheek bleed [44,45] Serum Creatine kinase activity was then determined with a Genzyme Creatine Kinase-SL Assay Kit (BioPacific Diagnostic Inc, Vancouver, BC, Canada).

\section{Real-time polymerase chain reaction}

Total RNA was isolated from mouse tissue using the TRIzol (Invitrogen, Grand Island, NY, USA) reagent, while RNA from cultured cells was isolated using the Turbocapture (Qiagen, Valencia, California, USA) method. Samples for real-time PCR analyses were reverse transcribed (Applied Biosystems, Foster City, California, USA), and quantitative real-time PCRs (qPCRs) were performed on the cDNAs in the presence of fluorescent dye (SYBR green) (Bio-Rad, Hercules, California, USA). Relative expression levels were determined using the comparative cycle threshold method [46].

\section{Western blotting}

Protein from quadriceps $(100 \mu \mathrm{g})$ was run on a $4 \%$ polyacrylamide gel, transferred to nitrocellulose membrane, and blotted for utrophin using an anti-utrophin antibody (H-300, Santa Cruz Biotech, Santa Cruz, California USA). As a control, equivalent protein was run on a $10 \%$ polyacrylamide gel, transferred and probed with anti-panactin antibody (Cell Signaling Technology Inc, Boston, Massachusetts, USA),

\section{Statistical analysis}

The data are presented as means \pm SEM. Statistical analysis was performed with Student's t-test for all in vitro experiments, analysis of variance for all in vivo experiments, and Log-rank (Mantel-Cox) test for the KaplanMeier curves. $P$ values $<0.05$ were considered statistically significant.

\section{Results}

PGC-1 $\beta$, in contrast to PGC-1 $\alpha$, does not induce expression of utrophin and other neuromuscular junction genes

We began our studies by investigating the role of PGC$1 \beta$, if any, in the pathogenesis of, and possible protection against, muscle dystrophy. Increased PGC-1 $\alpha$ has been shown to ameliorate muscle damage in $\mathrm{mdx}$ mice [17,31-34]. PGC-1 $\alpha$ has also been shown to be decreased in a dog model of DMD [47], suggesting that loss of PGC-1 $\alpha$ protection may contribute to the dystrophy. Similarly, we found that PGC-1 $\alpha$ mRNA expression, measured by $\mathrm{qPCR}$, is significantly reduced 
in gastrocnemius muscle from 5 -week-old $\mathrm{mdx}$ mice (Figure 1A). In contrast, expression of PGC-1 $\beta$ was not decreased in mdx mice, suggesting that PGC-1 $\beta$ may play a different role than PGC-1 $\alpha$ in mdx pathogenesis.

Because the anti-dystrophic effects of PGC-1 $\alpha$ have widely been ascribed to induction of the NMJ, and utrophin in particular, we next tested if PGC-1 $\beta$ also regulates this program. Five-week-old male mice with transgenic overexpression of PGC-1 $\alpha$ in muscle cells (MCK-PGC-1 $\alpha$ ) showed significant increase in expression of genes involved in the NMJ (for example, utrophin, acetylcholine receptor (AChR) $\alpha, \mathrm{AChR} \delta, \mathrm{AChR} \varepsilon$, acetylcholine esterase (AChEst), ErbB-2, GABPA, MUSK and Rapsyn) in the gastrocnemius, compared to littermate control animals (WT) (Figure 1B). Unlike PGC-1 $\alpha$, however, equivalent transgenic increase in PGC-1 $\beta$ expression in muscle cells (MCK-PGC-1 $\beta$ ) did not increase expression of genes of the NMJ (Figure 1B). In contrast, genes associated with oxidative phosphorylation (ox-phos) were significantly induced by transgenic overexpression of both PGC- $1 \alpha$ and PGC- $1 \beta$, as published previously [24]. Induction of ox-phos genes was equivalent if not slightly higher in MCK-PGC-1 $\beta$ animals, demonstrating that the non-induction of genes of the NMJ cannot be explained by poor activity of the transgenic PGC-1 $\beta$. Unbiased microarray analyses of RNAs from the quadriceps of MCK-PGC-1 $\beta$ mice versus littermate controls similarly revealed increased expression of mitochondrial genes compared to WT, but no change in genes of the NMJ (Figure 1C). Similarly, in cultured differentiated primary myotubes, infection with recombinant PGC- $1 \alpha$ adenovirus (Ad-PGC-1 $\alpha$ ) increased expression of both NMJ genes and ox-phos genes, while infection with recombinant PGC-1 $\beta$ (Ad-PGC-1 $\beta$ ) induced only ox-phos genes and had no effect on NMJ genes (Figure 1D). Together, these results indicate that, unlike PGC- $1 \alpha$, PGC- $1 \beta$ does not regulate expression of NMJ genes or utrophin in muscle cells or in vivo.

\section{PGC-1 $\beta$ prevents damage in dystrophic muscle}

The prevailing model of the mechanism by which PGC$1 \alpha$ ameliorates muscle damage is by positively regulating expression of genes of the NMJ, including utrophin. The above results demonstrating that PGC-1 $\beta$ does not induce this program thus suggest that PGC-1 $\beta$ transgenesis would fail to recapitulate the protection against dystrophy seen in PGC- $1 \alpha$ transgenic animals. To test this notion, we crossed mdx animals with MCK-PGC-1 $\beta$ (and, as

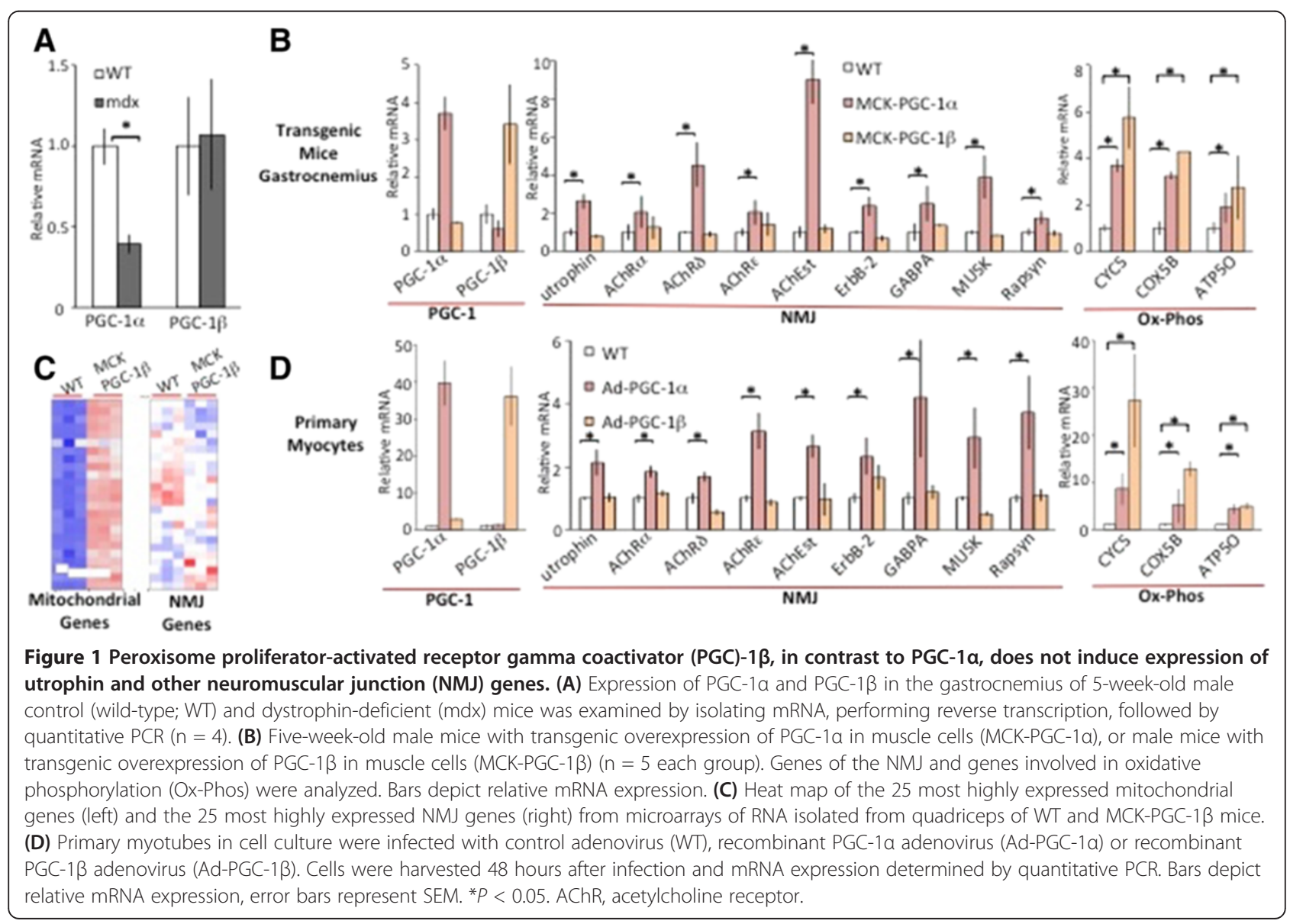


positive controls, MCK-PGC-1 $\alpha$ ) animals. Transgenic expression of PGC- $1 \alpha$ in mdx mice (mdx/MCK-PGC- $1 \alpha$ ) increased mRNA expression of NMJ genes and utrophin, as published previously (Figure 2A). Transgenic expression of PGC-1 $\beta$ ( $\mathrm{mdx} / \mathrm{MCK}-\mathrm{PGC} 1 \beta)$ did not induce this program, echoing the findings in non-dystrophic mice (Figure 1). Both PGC- $1 \alpha$ and PGC- $1 \beta$ induced the expression of ox-phos genes (Figure 2A). Utrophin protein was induced in $\mathrm{mdx} / \mathrm{MCK}-\mathrm{PGC}-1 \alpha$ quadriceps compared to quadriceps from mdx mice alone (Figure $2 \mathrm{~B}$ ), while $\mathrm{mdx} /$ MCK-PGC-1 $\beta$ mice showed no significant increase in utrophin protein. Therefore, unlike PGC- $1 \alpha$, PGC-1 $\beta$ does not induce utrophin or other proteins of the $\mathrm{NMJ}$ in $\mathrm{mdx}$ mice.

Next, we performed various experiments to determine the relative amount of damage and function in $\mathrm{mdx}$, $\mathrm{mdx} / \mathrm{MCK}-\mathrm{PGC}-1 \alpha$, and $\mathrm{mdx} / \mathrm{MCK}-\mathrm{PGC}-1 \beta$ mice. We first tested the level of serum creatine kinase. There was significant increase in free creatine kinase in the serum of $\mathrm{mdx}$ compared to WT mice (Figure 2C), consistent with increased muscle damage. The amount of serum creatine kinase was significantly suppressed in $\mathrm{mdx} /$ MCK-PGC- $1 \alpha$ compared to $\mathrm{mdx}$ alone, as previously shown [17], consistent with amelioration of dystrophy by PGC- $1 \alpha$ expression. Surprisingly, mdx/MCK-PGC-1 $\beta$ also had significantly lower levels of serum creatine kinase compared to $m d x$ alone, suggesting that PGC-1 $\beta$ is also protective in the mdx model.

We next stained cross-sections of the gastrocnemius with hematoxylin and eosin (Figure 2D). We observed that mdx mice had a greater number of centralized nuclei and smaller fiber size as previously reported [48]. Increased transgenic expression of PGC- $1 \alpha$ appeared to improve these phenotypes (Figure 2D). In order to better visualize and quantify these differences, we stained cross-sections of the gastrocnemius with anti-laminin to stain boundary of muscle fibers and counterstained with DAPI. Consistent with previous studies, $\mathrm{mdx}$ mice had a larger variation in fiber size and a larger proportion of small fibers compared to WT mice [48] (Figure 2E). The muscle fibers in $\mathrm{mdx} /$ MCK-PGC-1 $\alpha$ had a lower variation in size, and had fewer small fibers compared to $\mathrm{mdx}$ alone. Muscle fibers in the $m d x / M C K-P G C-1 \beta$ were similar to $m d x / M C K-P G C-1 \alpha$. PGC-1 $\beta$ transgenesis thus partly rescued the fiber size defect seen in mdx mice. We next measured the percentage of nuclei found in the center of muscle fibers (Figure 2F), an established model of estimating the number of postdamage regenerating fibers. The number of centralized nuclei in gastrocnemius of the $\mathrm{mdx}$ mice was approximately $17 \%$, while essentially no central nuclei were seen in WT animals. mdx/MCK-PGC- $1 \alpha$ mice had approximately $50 \%$ decrease in the number of centralized nuclei, consistent with partial rescue of the mdx phenotype. The number of centralized nuclei in $\mathrm{mdx} / \mathrm{MCK}-\mathrm{PGC}-1 \beta$ mice was similarly reduced compared to $\mathrm{mdx}$ alone. Similar findings were seen in quadriceps and tibialis anterior (data not shown).

The extravasation of Evans Blue dye into the muscle of mice is a standard measure of vascular and sarcolemmal integrity. As shown in Figure 2G, there was a significant increase in the amount of Evans Blue leakage into the gastrocnemius, the quadriceps and the tibialis anterior of mdx mice compared to WT, consistent with muscle damage and necrosis in mdx mice. Increased expression of PGC- $1 \alpha$ in $\mathrm{mdx} / \mathrm{MCK}-\mathrm{PGC}-1 \alpha$ mice lowered the intensity of Evans Blue dye in the different muscles, as previously reported [17]. Surprisingly again, increased expression of PGC-1 $\beta$ in $\mathrm{mdx} / \mathrm{MCK}-\mathrm{PGC}-1 \beta$ reduced Evans Blue extravasation equally effectively (Figure 2G).

\section{PGC-1 $\beta$ improves exercise capacity of dystrophic mice}

We next tested the effect of PGC- $1 \alpha$ or PGC- $1 \beta$ on $\mathrm{mdx}$ mice subjected to eccentric physical exercise:- that is, downhill running. The muscle damage observed in $\mathrm{mdx}$ mice subjected to eccentric exercise more closely resembles muscle damage seen in DMD patients [49]. WT, $\mathrm{mdx}, \mathrm{mdx} / \mathrm{MCK}$-PGC- $1 \alpha$ and mdx/MCK-PGC- $1 \beta$ mice were made to run on a treadmill for 1 hour at an decline of $15^{\circ}$ downhill. This exercise regimen was repeated 24 hours after the first run. WT mice were able to complete this exercise regimen, but $\mathrm{mdx}$ mice were exhausted within the first 5 to 10 minutes of the regimen (Figure 3A), as shown previously [17]. Both mdx/MCK-PGC- $1 \alpha$ and $\mathrm{mdx} /$ MCK-PGC-1 $\beta$ mice were able to run for significantly longer compared to $\mathrm{mdx}$ alone on both the $1^{\text {st }}$ and $2^{\text {nd }}$ run (Figure 3A). Serum was drawn from the animals 2 hours after each run, and serum creatine kinase measured. There was significant increase in creatine kinase of mdx mice compared to WT mice, consistent with significant induction of muscle damage by eccentric exercise (Figure 3B). Compared to $\mathrm{mdx}$ alone, both $\mathrm{mdx} / \mathrm{MCK}$ PGC- $1 \alpha$ and mdx/MCK-PGC- $1 \beta$ had significantly lower levels of serum creatine kinase, consistent with lower levels of muscle damage (Figure 3B). In fact, the improvement in creatine kinase leak seen in MCK-PGC-1 mice is likely an underestimate of true improvements conferred by PGC- 1 transgenesis, because the transgenic mice were able to run longer than the $\mathrm{mdx}$ controls. Similarly, muscle damage as determined by Evans Blue leakage into the muscle fibers was lower in the mdx/MCK-PGC- $1 \alpha$ and $\mathrm{mdx} / \mathrm{MCK}-\mathrm{PGC}-1 \beta$ compared to $\mathrm{mdx}$ alone (Figure $3 \mathrm{C}$ ). Together, these results indicate that overexpression of PGC- $1 \alpha$ or PGC- $1 \beta$ prevents muscle damage in $\mathrm{mdx}$ mice in response to eccentric physical exercise.

Taken together, these data show that PGC- $1 \beta$ is as effective as PGC- $1 \alpha$ in ameliorating muscle damage in both sedentary and eccentrically exercised $\mathrm{mdx}$ mice. As described above, however, overexpression of PGC-1 $\beta$ in 


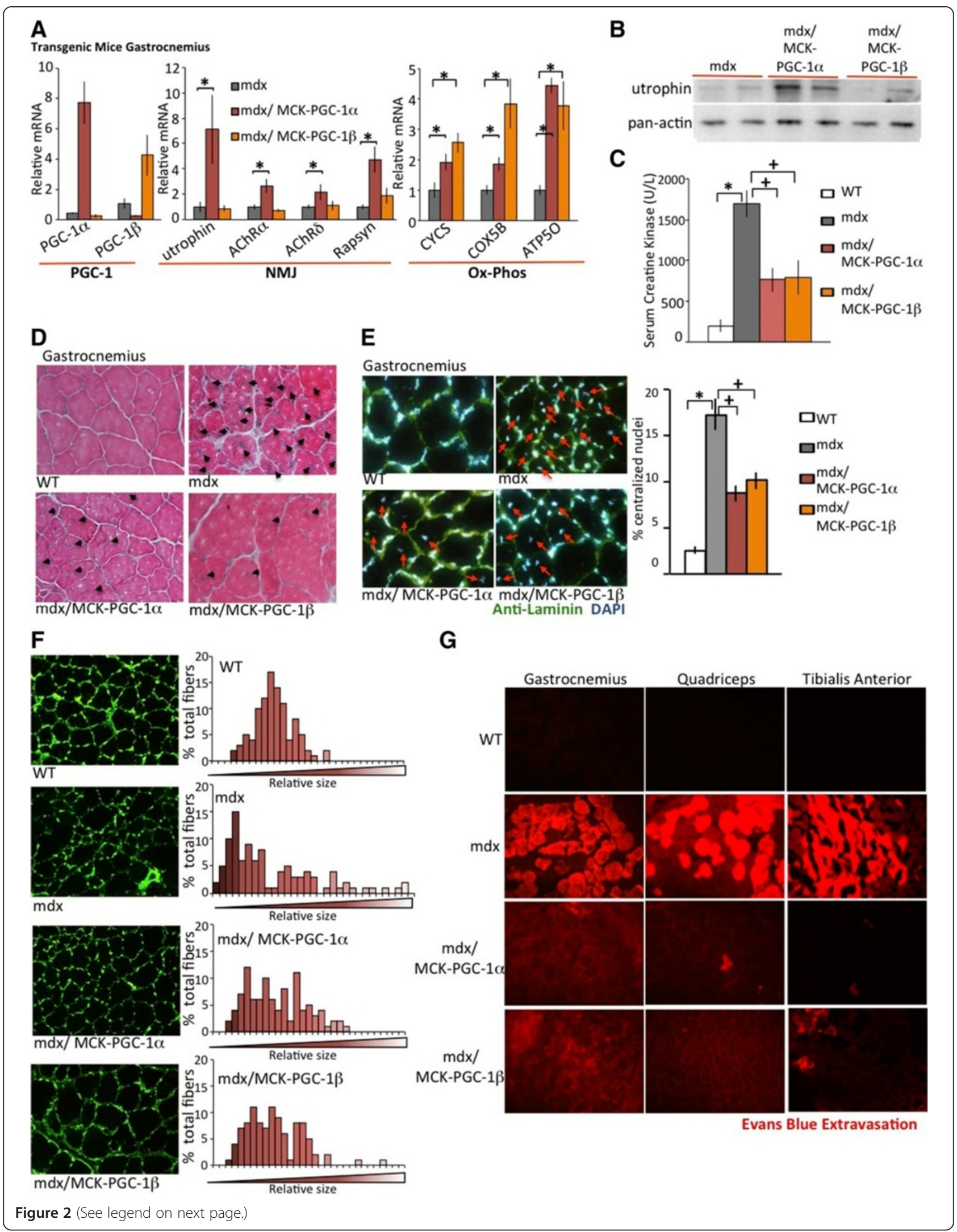


(See figure on previous page.)

Figure 2 Peroxisome proliferator-activated receptor gamma coactivator (PGC)-1 $1 \beta$ ameliorates muscle damage in dystrophin-deficient $(\mathbf{m d x})$ mice without induction of utrophin or other neuromuscular junction (NMJ) genes. (A) Five week old control (WT), $m d x, m d x \mathrm{mice}$ with overexpression of PGC-1a in muscle cells (mdx/MCK-PGC-1a), or mdx mice with overexpression of PGC-1 $\beta$ in muscle cells (mdx/MCK-PGC-1 3 ) ( $n=5$ each group) were sacked, and quantitative PCR was performed on mRNA isolated from the gastrocnemius. Genes of the NMJ and genes involved in oxidative phosphorylation (Ox-Phos) were analyzed. (B) Quadriceps from mdx, mdx/MCK-PGC-1a and mdx/MCK-PGC-1 $\beta$ were harvested and subjected to immunoblot analysis with anti-utrophin antibody and anti-pan-actin antibody. Results are representative of three independent experiments. (C) Five-week-old WT, mdx, MCK-PGC-1a and MCK-PGC-1 $\beta$ mice were sacked and serum creatine kinase activity was measured. Bars depict average serum creatine kinase activity $(n=5)$. (D) Histological sections from gastrocnemius of 5-week-old WT, mdx, MCK-PGC-1 1 and MCK-PGC-1 $\beta$ mice were prepared and stained with hematoxylin and eosin. Black arrows indicate centralized nuclei. (E) Histological sections from gastrocnemius of 5-week-old WT, mdx, MCK-PGC-1a and MCK-PGC-1 $\beta$ mice were stained with anti-laminin (green) to show muscle fiber boundaries and 4',6-diamidino-2-phenylindole (DAPI) to stain nuclei (blue). Representative images shown (left), with red arrows indicating centralized nuclei. Bars (right) depict percentage of nuclei counted which were centralized $(n=5)$. (F) Images of the same section were analyzed for relative fiber size using ImageJ. Bar histograms represent size distribution of the muscle fibers (right). (G) Five-week-old WT, mdx, MCK-PGC-1a and MCK-PGC-1 $\beta$ mice were injected intraperitoneally with $1 \% \mathrm{v} / \mathrm{w}$ Evans Blue solution and sacrificed 16 hours later. Histological sections from gastrocnemius, quadriceps and tibialis anterior were analyzed for dye incorporation into muscle fibers by fluorescence microscopy. Representative images are presented. Error bars represent $S E M . ~ * P<0.05$. AChR, acetylcholine receptor.

myotubes or in vivo does not induce utrophin or other components of the NMJ. This observation strongly suggests that the mechanism by which PGC- $1 \alpha$ and PGC-1 $\beta$ ameliorates muscle damage in $\mathrm{mdx}$ mice is not related to induction of components of the NMJ.

\section{Increased PGC-1a expression in dystrophic muscle ameliorates damage in the absence of utrophin} As outlined above, our results with MCK-PGC- $1 \beta$ mice support the hypothesis that the beneficial impact of PGC- $1 \alpha$ in mdx mice occurs independently of utrophin induction. We next directly tested this hypothesis by using mice that lack both dystrophin and utrophin (mdx/ $\left.u_{t r n}^{-1-}\right)$. Previous reports have shown that these mice suffer from a more severe dystrophy compared to $\mathrm{mdx}$ mice alone [11-13]. The progression of dystrophy and reduced lifespan of these mice more closely recapitulates progression of DMD in humans [15]. We first tested the effect of overexpression of PGC-1 $\alpha$ in muscle of these mice (mdx/utrn ${ }^{-1-} / \mathrm{MCK}-\mathrm{PGC}-1 \alpha$ ) on induction of NMJ and ox-phos genes. Similar to mdx mice, components of NMJ and ox-phos genes were induced in the mdx/utrn ${ }^{-/}$ mice (Figure 4A). The mutation in the utrn gene results in premature translation termination, and utrophin mRNA is still present (as previously reported [11]) and induced by PGC-1 $\alpha$ (Figure 4A). However, utrophin protein is
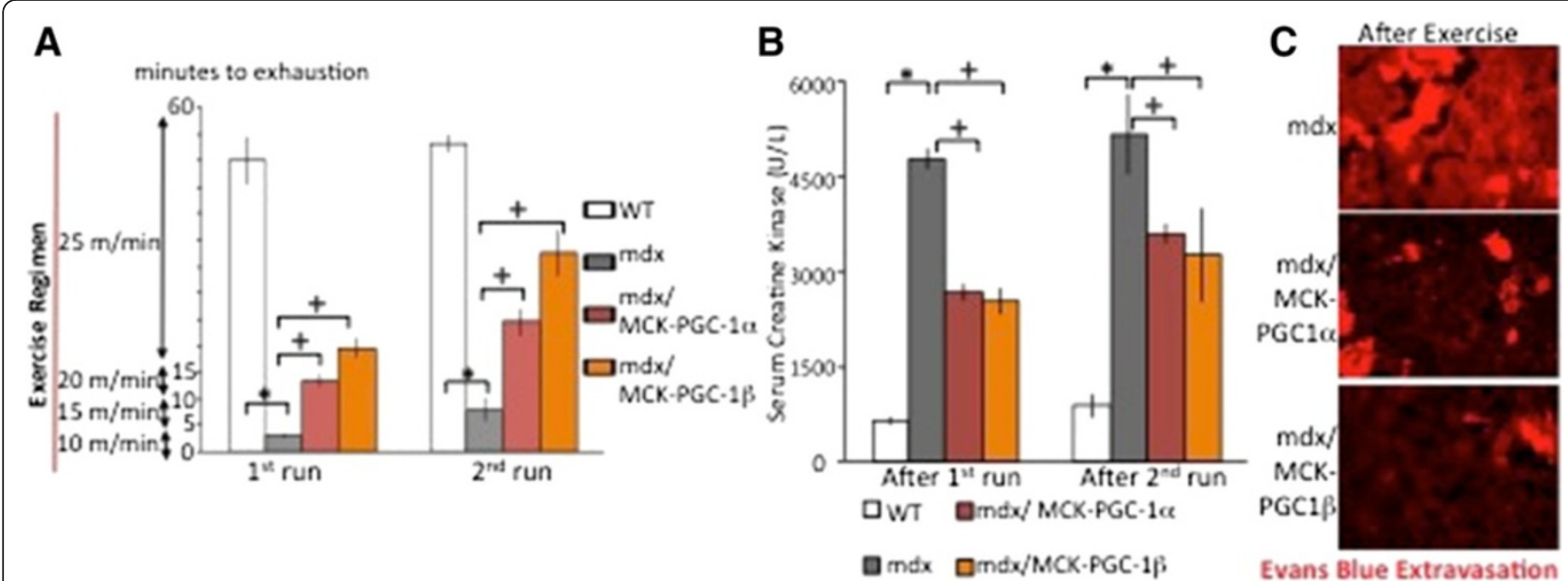

Figure 3 Peroxisome proliferator-activated receptor gamma coactivator (PGC)-1a and PGC-1 $\beta$ improve muscle function in exercising dystrophin-deficient (mdx) mice. (A) Ten-week-old control (wild-type; WT), mdx, mdx mice with transgenic overexpression of PGC-1a in muscle cells (mdx/MCK-PGC-1a), or mdx mice with transgenic over-expression of PGC-1 3 in muscle cells (mdx/MCK-PGC-1 $\beta$ ) ( $n=5$ each group) were run for 1 hour or until exhaustion on a treadmill at a $15^{\circ}$ downhill angle with steadily increasing speed as described in the methods ( $1^{\text {st }}$ run). This exercise protocol was repeated after a 24 hour resting period ( $2^{\text {nd }}$ run). Bars depict average running time. (B) Two hours after the first run, blood was drawn from mice by submandibular bleeding. Serum creatine kinase was determined ( ${ }^{\text {st }}$ run). Two hours after the second run, mice were sacked and blood was drawn. Serum creatine kinase was determined ( $2^{\text {nd }}$ run). (C) Evans Blue was injected intraperitoneally 16 hours before sacking and histological sections from gastrocnemius were analyzed by fluorescence microscopy. Error bars represent SEM. ${ }^{*} P<0.05$. 


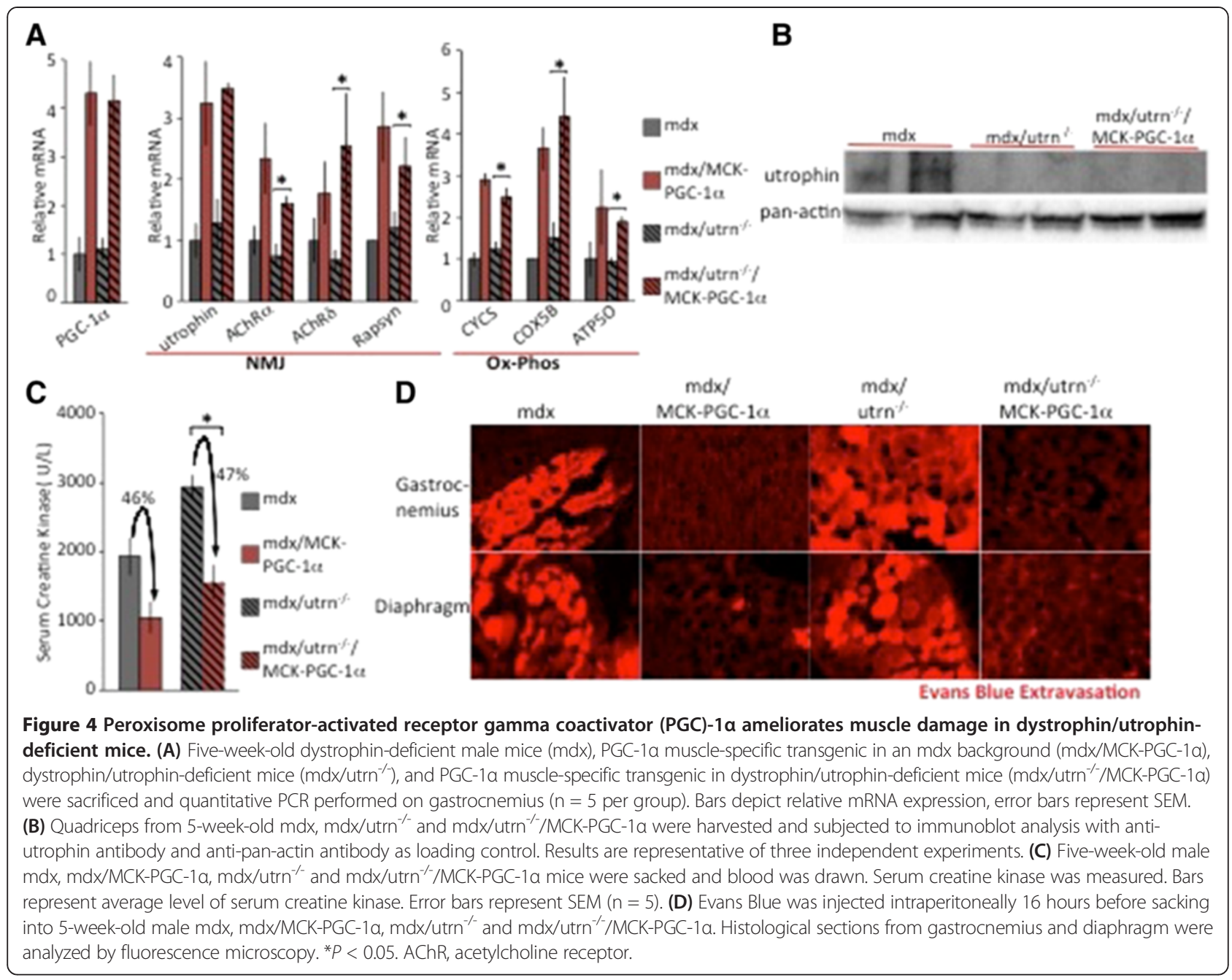

absent in $\mathrm{mdx} / \mathrm{utrn}^{-/-}$and $\mathrm{mdx} / \mathrm{utrn}^{-/-} / \mathrm{MCK}^{-P G C-1} \alpha$ mice (Figure 4B), as expected.

We next tested the effects of PGC- $1 \alpha$ expression on muscle damage in $\mathrm{mdx} / \mathrm{utrn}^{-1-}$ mice. Serum creatine kinase levels were higher in $\mathrm{mdx} / \mathrm{utrn}^{-1-}$ mice compared to $\mathrm{mdx}$ alone, consistent with a more severe progression of dystrophy (Figure 4C). PGC-1 $\alpha$ expression reduced serum creatine kinase by $47 \%$, comparing $\mathrm{mdx} / \mathrm{utrn}^{-/} / \mathrm{MCK}-$ PGC-1 $\alpha$ mice to $\mathrm{mdx} / \mathrm{utrn}^{-/-}$alone. This is similar to the $46 \%$ reduction in serum creatine kinase with expression of PGC-1 $\alpha$ in $\mathrm{mdx}$ mice (Figure 4C), demonstrating that PGC- $1 \alpha$ protects against muscle dystrophy as efficiently in the absence of utrophin as in its presence. Similar results were observed with Evans Blue incorporation experiments. Evans Blue staining in the fibers of the gastrocnemius and diaphragm was higher in $\mathrm{mdx} / \mathrm{utrn}^{-1-}$ mice compared to mdx mice (Figure 4D), and the intensity of staining was markedly reduced in $\mathrm{mdx} / \mathrm{utrn}^{-/} / \mathrm{MCK}-\mathrm{PGC}-1 \alpha$ compared to $\mathrm{mdx} / \mathrm{utrn}^{-1-}$ alone (Figure 4D).

The $\mathrm{mdx} / \mathrm{utrn}^{-/-}$mice suffer from poor growth, significant kyphosis and reduced life-span compared to $\mathrm{mdx}$ mice $[12,13]$. We examined if overexpression of PGC-1 $\alpha$ in skeletal muscle would affect any of these phenotypes. Physical examination of 5-week-old mice revealed that the $\mathrm{mdx} / \mathrm{utrn}^{-1-}$ mice were smaller and appeared more hunched compared to mdx mice. In comparison, $\mathrm{mdx} /$ $u_{t r n}{ }^{-/} /$MCK-PGC-1 $\alpha$ mice appeared larger than $\mathrm{mdx} /$ $\mathrm{utrn}^{-1-}$ mice (Figure 5A) and appeared indistinguishable from $\mathrm{mdx}$ mice. Radiography of $\mathrm{mdx} / \mathrm{utrn}^{-/}$revealed severe kyphosis compared to $\mathrm{mdx}$ mice (Figure $5 \mathrm{~B}$ ). In contrast, kyphosis in $\mathrm{mdx} / \mathrm{utrn}^{-/} / \mathrm{MCK}-\mathrm{PGC}-1 \alpha$ was largely absent (Figure 5B). Body weight and body length (nose to tail) of mdx, mdx/MCK-PGC-1 $\alpha, \mathrm{mdx} / \mathrm{utrn}^{-1 /}$, and $\mathrm{mdx} / \mathrm{utrn}^{-1-} / \mathrm{MCK}-\mathrm{PGC}-1 \alpha$ mice were measured between 5 and 15 weeks of age (Figure $5 \mathrm{C}$ ). There was no significant difference in body weight or length between $\mathrm{mdx}$ and $\mathrm{mdx} / \mathrm{MCK}-\mathrm{PGC}-1 \alpha$ mice. $\mathrm{mdx} / \mathrm{utrn}^{-/}$, however, were significantly lighter and smaller compared to $\mathrm{mdx}$ mice alone (Figure 5C). In contrast, $\mathrm{mdx} / \mathrm{utrn}^{-1-}$ MCK-PGC-1 $\alpha$ mice were heavier, and had longer body length compared to $\mathrm{mdx} / \mathrm{utrn}^{-1-}$ mice. The life span of $\mathrm{mdx}$ mice is reported to be up to 2 years. The life span 


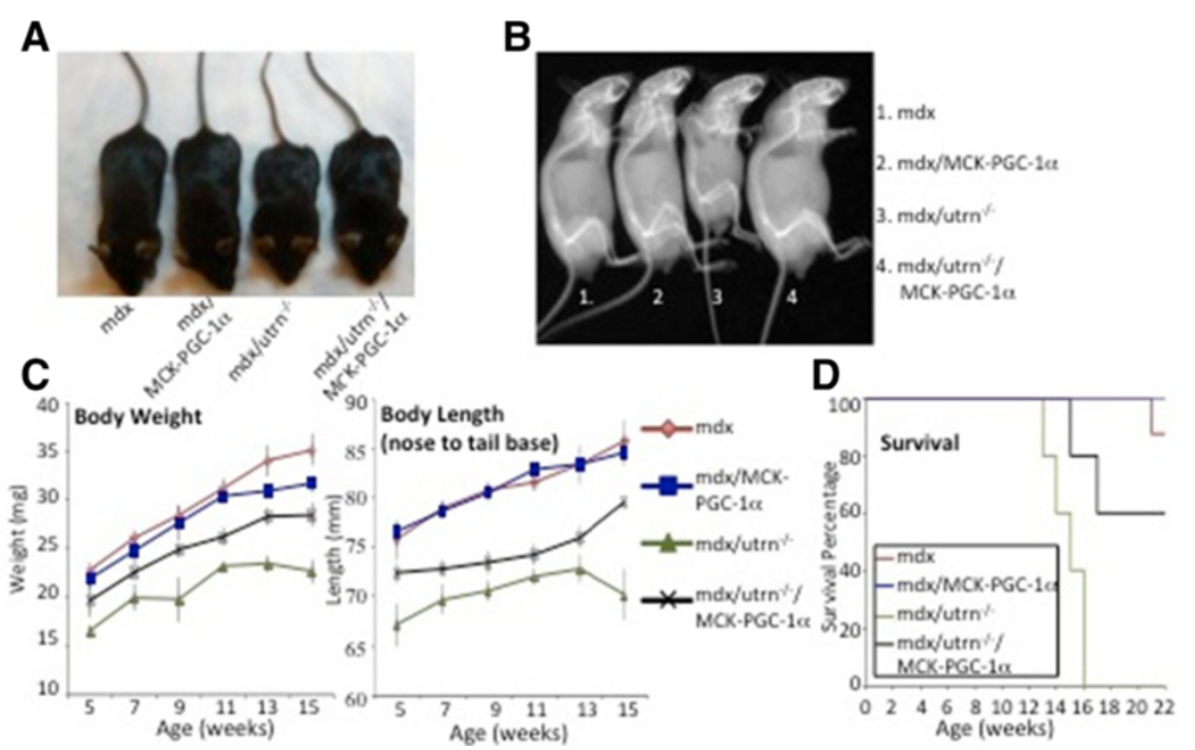

Figure 5 Peroxisome proliferator-activated receptor gamma coactivator (PGC)-1a reverses poor growth and kyphosis in dystrophin/ utrophin-deficient mice. (A) Photograph of representative 5-week-old dystrophin deficient male mice (mdx), PGC-1a muscle-specific transgenic in an mdx background (mdx/MCK-PGC-1a), dystrophin/utrophin-deficient mice (mdx/utrn ${ }^{-1}$ ), and PGC-1a muscle-specific transgenic in dystrophin/utrophin-deficient mice (mdx/utrn ${ }^{-1 /}$ MCK-PGC-1a) indicating difference in size and pronounced kyphosis in mdx/utrn ${ }^{-1-}$ that is largely reversed in mdx/utrn ${ }^{-1} /$ MCK-PGC-1a animals. (B) Representative radiograph of 13-week-old male mdx, $\mathrm{mdx} / \mathrm{MCK}-\mathrm{PGC}-1 \mathrm{a}, \mathrm{mdx} / \mathrm{utrn}^{-/}$ and $\mathrm{mdx} / \mathrm{utrn}^{-/} / \mathrm{MCK}-\mathrm{PGC}-1$ a mice showing small size and pronounced kyphosis in mdx/utrn ${ }^{-1-}$ mice is largely reversed in $\mathrm{mdx} / \mathrm{utrn}^{-/} / \mathrm{MCK}-$ PGC-1a mice. (C) Body weight (left) and body length from nose to tail base (right) of $m d x(n=8), m d x / M C K-P G C-1 a(n=8), m d x / u t r n n^{-1-}(n$ $=5)$ and $\mathrm{mdx} / \mathrm{utrn}^{-1} / \mathrm{MCK}-\mathrm{PGC}-1 \mathrm{a}(\mathrm{n}=5)$ male mice were measured every 2 weeks from 5 to 15 weeks of age. Graph represents average body weight and average body length, error bars SEM. (D) Kaplan-Meier survival plot of $\mathrm{mdx}(n=8), \mathrm{mdx} / \mathrm{MCK}-\mathrm{PGC}-1 \mathrm{a}(\mathrm{n}=8)$, $\mathrm{mdx} / \mathrm{utrn}{ }^{-1-}$ $(\mathrm{n}=5)$ and $\mathrm{mdx} / \mathrm{utrn}^{-1} /$ MCK-PGC-1a $(\mathrm{n}=5)$ male mice with time. $P<0.02$ by Log-rank (Mantel-Cox) test for mdx/utrn ${ }^{-/-}$compared to mdx/utrn ${ }^{-/} /$MCK-PGC-1a cohorts.

of the $\mathrm{mdx} / \mathrm{utrn}^{-1-}$ mice, in contrast, is shortened, with all mice in our cohort dying at between 13 and 17 weeks of age (Figure 5D). The mdx/utrn ${ }^{-1} /$ MCK-PGC- $1 \alpha$ mice showed an increase in life span, with $60 \%$ of mice remaining alive after 18 weeks (compared to $0 \%$ of $\mathrm{mdx} / \mathrm{utrn}^{-1-}$ mice) $\left(P<0.02\right.$ versus $\mathrm{mdx} / \mathrm{utrn}^{-/-}$mice $)$.

Together, these results demonstrate that overexpression of PGC- $1 \alpha$ in muscle rescues dystrophy independently of utrophin. The results also show that muscle PGC- $1 \alpha$ dramatically improves myopathy and wholebody sequelae in $\mathrm{mdx} / \mathrm{utrn}^{-1-}$ mice, a more severe dystrophic model that more closely approximates the human disease.

\section{Postnatal increase in PGC-1a expression in muscle improves dystrophic muscle}

The above experiments underscore PGC- $1 \alpha$ as a potential therapeutic target for DMD. However, in all of these mice as well as those previously published [17], PGC-1 $\alpha$ overexpression in skeletal muscle begins in utero. Dystrophindeficient muscle reveals significant abnormalities even prenatally $[35,36]$, suggesting that prenatal expression of PGC-1 $\alpha$ may have had important beneficial effects that would be difficult to recapitulate in the clinical setting. We thus wanted to test if post-natal increase in PGC- $1 \alpha$ expression can reduce muscle damage in mdx mice. To conduct this experiment, we used double-transgenic mice (MCK-tTA/TRE-PGC-1 $\alpha$ ) as described in Figure 6A and the Methods section. Induction of PGC- $1 \alpha$ thus occurs only with removal of doxycycline from chow (Figure 6A). These mice were then additionally bred into the $\mathrm{mdx}$ background. Mice were switched to chow lacking doxycycline at the age of 3 weeks and were examined 4 weeks later. We first confirmed that induction of PGC$1 \alpha$ was successful, observing an approximate 4 -fold increase in PGC- $1 \alpha$ expression, both in $\mathrm{mdx}$ and WT backgrounds (Figure 6B), and mildly less than observed in constitutive $\mathrm{mdx} / \mathrm{MCK}-\mathrm{PGC}-1 \alpha$ mice (Figure $2 \mathrm{~A}$ ). We also observed corresponding increase in NMJ and ox-phos genes with PGC-1 $\alpha$ induction in both genetic backgrounds (Figure 6B).

We next tested if induction of post-natal induction of PGC- $1 \alpha$ affects dystrophic muscle damage in $\mathrm{mdx}$ mice. Serum creatine kinase was significantly reduced by $28 \%$ (Figure 6C) after PGC-1 $\alpha$ induction. Evans Blue staining of muscle was also reduced in $\mathrm{mdx} / \mathrm{Ind}$ _PGC- $1 \alpha$ mice compared to $\mathrm{mdx}$ mice (Figure 6D). Lastly, we examined the number of central nuclei found within the muscle fibers, an established measure of post-damage regenerating fibers in mice. There were no centralized 


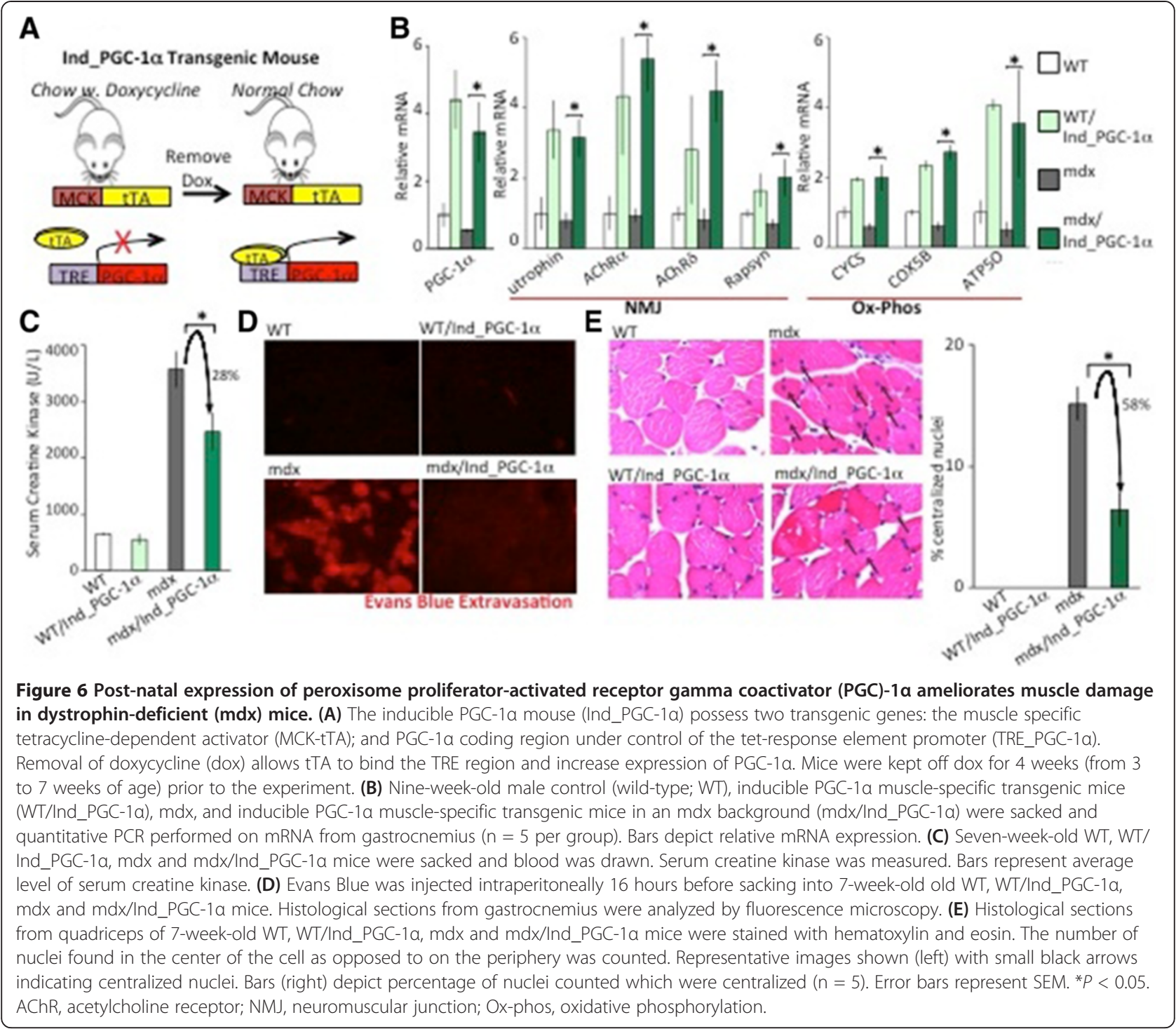

nuclei observed in WT or WT/Ind_PGC-1 $\alpha$ mice, while approximately $18 \%$ of nuclei in $\mathrm{mdx}$ mice were found in the center of cells (Figure 6E). Induction of PGC- $1 \alpha$ significantly decreased the number of centralized nuclei by $58 \%$ compared to mdx mice. From these results, we conclude that post-natal induction of PGC- $1 \alpha$ is able to efficiently prevent muscle damage in $\mathrm{mdx}$ mice.

\section{Discussion}

We demonstrate in this study that: both PGC- $1 \alpha$ and PGC- $1 \beta$ improve muscle function in dystrophic mouse models; that they do so independently of utrophin induction; that PGC-1 $\alpha$ improves muscle function even if delivered only post-natally; and that even the more severe $\mathrm{mdx}$ / $u_{t r n}{ }^{-/}$model of DMD is efficiently rescued by PGC- $1 \alpha$.

The induction of utrophin efficiently rescues the absence of dystrophin in muscle $[2,3,10,16,50]$ and has thus generally been assumed to explain the benefits conferred by PGC-1 $\alpha[17,31,33]$. The present study, however, demonstrates that this is not the case. The data demonstrate the existence of other beneficial pathways. Identifying these pathways will be of great interest, especially in light of the efficient protection afforded by PGC- $1 \alpha$ induction. A number of potential mechanisms exist. ATP deficiency may contribute to myocyte death, and PGC-1 induction, leading to mitochondrial biogenesis and increased OXPHOS capacity, significantly increases the capacity for ATP generation. Mitochondria also provide a large buffer for cytosolic calcium, and cytosolic calcium overload in dystrophic muscle is thought to contribute to the activation of calpains and caspases, ultimately leading to myocyte apoptosis. PGC-1-induced mitochondrial biogenesis may thus buffer cytosolic calcium and help prevent these events. PGC-1s have also 
been shown widely, especially in neurobiological contexts, to reduce cellular levels of reactive oxygen species (ROS) [51-53], and ROS have also been implicated in dystrophic pathophysiology [54-57]. Finally, PGC-1 $\alpha$ may suppress the susceptibility of mitochondrial permeability transition pore (PTP) to open [58], again minimizing the tendency to apoptosis. The fact that one or more of these mechanisms must underlie the powerful PGC-1 $\alpha$-mediated protection underscores the need to better understand these processes.

Despite the fact that it does not induce genes of the NMJ, our data supports the use of PGC-1 $\beta$ as a possible alternative therapeutic target in DMD. Why PGC- $1 \beta$ fails to induce utrophin and other NMJ genes is not clear. PGC-1 $\beta$ likely interacts efficiently with NRF2, because it strongly induces mitochondrial genes $[19,24]$. The specific inability to induce genes of the NMJ thus likely does not stem from an inability to bind GABPA/B tetramers (NRF2). Post-translational modification of GABPA and PGC- $1 \alpha$ by p38MAPK has been shown to be important for induction of NMJ genes [17], and this process may differ with PGC-1 $\beta$. The p38MAPK sites in PGC- $1 \alpha$ are, for example, not conserved in PGC-1 $\beta$.

PGC $-1 \alpha$ and $\beta$ strongly drive the formation of oxidative fibers at the expense of glycolytic fibers [38-40]. DMD in humans has been shown to affect type II glycolytic fibers more severely than type I oxidative fibers [59]. This observation has been attributed to the observation that utrophin expression is higher in oxidative fibers, and that utrophin protein in these fibers can be found extra-synaptically, where it would more easily compensate for loss of dystrophin [32,60]. Our current work would suggest, however, that utrophin expression and distribution does not underlie these differences in myofiber susceptibility to DMD, underscoring the need to better understand other protective mechanisms induced by the PGC-1s.

Dystrophy in mdx/utrn ${ }^{-1-}$ mice is much more severe than in mdx mice alone. The mice undergo significant muscle degeneration early in life, with pronounced systemic consequences such as kyphosis, delayed growth, and eventual premature death by 3 to 4 months of age [11-14]. mdx mice, on the other hand, recover efficiently from their repeated bouts of dystrophy, do not have overt systemic phenotypes, and have a normal life span $[15,61]$. The mdx/utrn ${ }^{-1-}$ mouse model thus recapitulates the clinical spectrum of human DMD much more faithfully than do mdx mice. Our data showing that PGC- $1 \alpha$ transgenesis efficiently rescues all of these phenotypes in $\mathrm{mdx} / \mathrm{utrn}^{-/-}$mice thus underscores the potential clinical value of targeting PGC-1 $\alpha$ and/or its mechanism(s) of action. It will also be of interest to test if PGC- $1 \alpha$ can rescue other more severe models of dystrophy, such as telomerase-deficient mice [62].
Together, these results strongly support PGC- $1 \alpha$ as a potential therapeutic target for DMD. One approach to this target is gene therapy. Recent reports have suggested that viral or plasmid delivery of PGC-1 $\alpha$ post-natally can improve muscle function in mdx mice [32,63]. Our data support this conclusion, and show that PGC-1 $\alpha$ expression specifically in myotubes likely mediates this protection. Another approach could use pharmaceutical activation of the PGC-1 $\alpha$ pathway. Recent reports have reported benefits in $\mathrm{mdx}$ mice with administration of activators of AMPK, SIRT1, or PPAR $\delta$, all of which also activate PGC-1 $\alpha$ [34,64-66].

\section{Conclusions}

Our data demonstrate that increased expression of either PGC- $1 \alpha$ or PGC-1 $\beta$ in skeletal muscle ameliorates muscle damage in mouse models of DMD. We show that this benefit occurs independently of utrophin or increases in NMJ components. We also demonstrate that post-natal induction of PGC-1 $\alpha$ is also beneficial in mdx mice, and that even the more severe $\mathrm{mdx} / \mathrm{utrn}^{-/-}$model of DMD is efficiently rescued by PGC- $1 \alpha$. PGC- $1 \alpha$ and PGC- $1 \beta$ thus represent viable therapeutic targets for DMD, but the mechanisms by which they reduce muscle damage in mouse models of DMD remain unclear and should be the subject of future investigations.

\section{Abbreviations}

AChR: acetylcholine receptor; AChEst: acetylcholine esterase; DGC: dystroglycan complex; DMD: Duchenne muscle dystrophy; DMEM: Dulbecco's modified Eagle's medium; ERRa: estrogen-related receptor a; GABPA: GA-binding protein a chain; GABPB: GA-binding protein $\beta$ chain; mdx: dystrophin-deficient; NMJ: neuromuscular junction; NRF: nuclear respiratory factor; ox-phos: oxidative phosphorylation; PCR: polymerase chain reaction; PGC: peroxisome proliferator-activated receptor gamma coactivator; qPCR: quantitative real-time PCR; ROS: reactive oxygen species; WT: wild-type.

\section{Competing interests}

The authors declare that they have no competing interests.

\section{Authors' contributions}

MCC designed and conducted experiments; wrote and edited the manuscript. GCR, SR, ISP and CF contributed to conducting experiments. ZA contributed to experimental design, wrote and edited the manuscript. All authors read and approved the final manuscript.

\section{Acknowledgements}

We thank Dr Matthew Alexander and Dr Louis Kunkel for advice and technical assistance. We thank Dr Kazusa Sato for radiography assistance. The NIAMS (GCR), NHLBI (ZA), the Ellison Foundation (ZA), the MDA (ZA) and the NRSA (SR) supported this work.

Received: 27 September 2013 Accepted: 23 December 2013 Published: 22 January 2014

\section{References}

1. Vilquin J-T, Catelain C, Vauchez K: Cell therapy for muscular dystrophies: advances and challenges. Curr Opin Organ Transplant 2011, 16:640-649.

2. Fairclough RJ, Bareja A, Davies KE: Progress in therapy for Duchenne muscular dystrophy. Exp Physio/ 2011, 96:1101-1113.

3. Bogdanovich S, Perkins KJ, Krag TOB, Khurana TS: Therapeutics for Duchenne muscular dystrophy: current approaches and future directions. J Mol Med 2004, 82:102-115. 
4. Kornberg A, Yiu E: Duchenne muscular dystrophy. Neurol India 2008, 56:236-247.

5. Koenig M, Hoffman EP, Bertelson CJ, Monaco AP: Complete cloning of the Duchenne muscular dystrophy (DMD) CDNA and preliminary genomic organization of the DMD gene in normal and affected individuals. Cell 1987, 50:509-517.

6. Muntoni F, Torelli S, Ferlini A: Dystrophin and mutations: one gene, several proteins, multiple phenotypes. Lancet Neurol 2003, 2:731-740.

7. Ervasti JM, Ohlendieck K, Kahl SD, Gaver MG, Campbell KP: Deficiency of a glycoprotein component of the dystrophin complex in dystrophic muscle. Nat Cell Biol 1990, 345:315-319.

8. Mercuri E, Sewry C, Brown SC, Muntoni F: Congenital muscular dystrophies. Semin Pediatr Neurol 2002, 9:120-131.

9. Haenggi T, Fritschy J-M: Role of dystrophin and utrophin for assembly and function of the dystrophin glycoprotein complex in non-muscle tissue. Cell Mol Life Sci 2006, 63:1614-1631.

10. Tinsley J, Deconinck N, Fisher R, Kahn D, Phelps S, Gillis JM, Davies K: Expression of full-length utrophin prevents muscular dystrophy in $\mathrm{mdx}$ mice. Nat Med 1998, 4:1441-1444

11. Deconinck AE, Rafael JA, Skinner JA, Brown SC, Potter AC, Metzinger L, Watt DJ, Dickson JG, Tinsley JM, Davies KE: Utrophin-dystrophin-deficient mice as a model for Duchenne muscular dystrophy. Cell 1997, 90:717-727.

12. Janssen PML: Utrophin deficiency worsens cardiac contractile dysfunction present in dystrophin-deficient mdx mice. AJP: Heart Circulat Physiol 2005, 289: $\mathrm{H} 2373-\mathrm{H} 2378$.

13. Grady RM, Teng H, Nichol MC, Cunningham JC: Skeletal and cardiac myopathies in mice lacking utrophin and dystrophin: a model for Duchenne muscular dystrophy. Cell 1997, 90:729-738.

14. Grady RM, Merlie JP, Sanes JR: Subtle neuromuscular defects in utrophin-deficient mice. J Cell Biol 1997, 136:871-882.

15. Nakamura A, Takeda S: Mammalian models of Duchenne muscular dystrophy: pathological characteristics and therapeutic applications. J Biomed Biotechnol 2011, 2011:1-8.

16. Rafael JA, Tinsley JM, Potter AC, Deconinck AE: Skeletal muscle-specific expression of a utrophin transgene rescues utrophin-dystrophin deficient mice. Nature 1998, 19:79-82.

17. Handschin C, Kobayashi YM, Chin S, Seale P, Campbell KP, Spiegelman BM: PGC-1 regulates the neuromuscular junction program and ameliorates Duchenne muscular dystrophy. Genes Dev 2007, 21:770-783.

18. Kelly DP, Scarpulla RC: Transcriptional regulatory circuits controlling mitochondrial biogenesis and function. Genes Dev 2004, 18:357-368.

19. Lin J, Handschin C, Spiegelman BM: Metabolic control through the PGC-1 family of transcription coactivators. Cell Metab 2005, 1:361-370.

20. Shoag J, Arany Z: Regulation of hypoxia-inducible genes by PGC-1a. Arteriosclerosis 2010, 30:662-666.

21. Benton CR, Holloway GP, Han XX, Yoshida Y, Snook LA, Lally J, Glatz JFC, Luiken JJFP, Chabowski A, Bonen A: Increased levels of peroxisome proliferator-activated receptor gamma, coactivator 1 alpha (PGC-1a) improve lipid utilisation, insulin signalling and glucose transport in skeletal muscle of lean and insulin-resistant obese Zucker rats. Diabetologia 2010, 53:2008-2019.

22. Kleiner S, Mepani RJ, Laznik D, Ye L, Jurczak MJ, Jornayvaz FR, Estall JL, Chatterjee Bhowmick D, Shulman Gl, Spiegelman BM: Development of insulin resistance in mice lacking PGC-1a in adipose tissues. Proc Natl Acad Sci USA 2012, 109:9635-9640.

23. Mueller $\mathrm{E}$ : Understanding the variegation of fat: novel regulators of adipocyte differentiation and fat tissue biology. Biochimica et Biophysica Acta (BBA)-Mol Basis 2013. in press.

24. Liu C, Lin JD: PGC-1 coactivators in the control of energy metabolism. Acta Biochim Biophys Sin 2011, 43:248-257.

25. Scarpulla RC: Metabolic control of mitochondrial biogenesis through the PGC-1 family regulatory network. Biochem Pharmacol 1813, 2011:1269-1278.

26. Jiang A, Arany Z: PGC-1 coactivators in cardiac development and disease. Circ Res 2010, 107:825-838.

27. Chinsomboon J, Ruas J, Gupta RK, Thom R, Shoag J, Rowe GC, Sawada N, Raghuram S, Arany Z: The transcriptional coactivator PGC-1alpha mediates exercise-induced angiogenesis in skeletal muscle. Proc Natl Acad Sci USA 2009, 106:21401-21406

28. Rowe GC, Jang C, Patten IS, Arany Z: PGC-1 $\beta$ regulates angiogenesis in skeletal muscle. AJP: Endocrin Metab 2011, 301:E155-E163.
29. Angus LM: Calcineurin-NFAT signaling, together with GABP and peroxisome PGC-1, drives utrophin gene expression at the neuromuscular junction. AJP: Cell Physiol 2005, 289:C908-C917.

30. Gordon BS, Delgado Díaz DC, Kostek MC: Resveratrol decreases inflammation and increases utrophin gene expression in the $\mathrm{mdx}$ mouse model of duchenne muscular dystrophy. Biochem Pharmacol 2013, 32:104-111.

31. Hollinger K, Gardan-Salmon D, Santana C, Rice D, Snella E, Selsby JT: Rescue of dystrophic skeletal muscle by PGC-1 involves restored expression of dystrophin-associated protein complex components and satellite cell signaling. AJP: Regulat Integrat Comparat Physiol 2013, 305:R13-R23.

32. Selsby JT, Morine KJ, Pendrak K, Barton ER, Sweeney HL: Rescue of dystrophic skeletal muscle by PGC-1a involves a fast to slow fiber type shift in the mdx mouse. PLoS One 2012, 7:e30063.

33. Miura S, Kawanaka K, Kai Y, Tamura M, Goto M, Shiuchi T, Minokoshi Y, Ezaki $O$ : An increase in murine skeletal muscle peroxisome proliferatoractivated receptor- coactivator-1 (PGC-1) mRNA in response to exercise is mediated by beta-adrenergic receptor activation. Endocrinology 2007, 148:3441-3448.

34. Ljubicic V, Miura P, Burt M, Boudreault L, Khogali S, Lunde JA, Renaud J-M, Jasmin BJ: Chronic AMPK activation evokes the slow, oxidative myogenic program and triggers beneficial adaptations in $\mathrm{mdx}$ mouse skeletal muscle. Hum Mol Genet 2011, 20:3478-3493.

35. Schiaffino S, Sandri M, Murgia M: Activity-dependent signaling pathways controlling muscle diversity and plasticity. Physiology (Bethesda) 2007, 22:269-278.

36. Merrick D, Stadler LK, Larner D, Smith J: Muscular dystrophy begins early in embryonic development deriving from stem cell loss and disrupted skeletal muscle formation. Disease Models \& Mechanisms 2009, 2:374-388.

37. Bulfield G, Siller WG, Wight PA, Moore KJ: X chromosome-linked muscular dystrophy (mdx) in the mouse. Proc Natl Acad Sci USA 1984, 81:1189-1192.

38. Lin J, Wu H, Tarr PT, Zhang C-Y, Wu Z, Boss O, Michael LF, Puigserver P, Isotani E, Olson EN, Lowell BB, Bassel-Duby R, Spiegelman BM: Transcriptional co-activator PGC-1a drives the formation of slow-twitch muscle fibres. Nat Cell Biol 2002, 418:797-801.

39. Arany Z, Lebrasseur N, Morris C, Smith E, Yang W, Ma Y, Chin S, Spiegelman BM: The transcriptional coactivator PGC-1 beta drives the formation of oxidative type IIX fibers in skeletal muscle. Cell Metab 2007, 5:35-46.

40. Wende AR, Schaeffer PJ, Parker GJ, Zechner C, Han D-H, Chen MM, Hancock CR, Lehman JJ, Huss JM, McClain DA, Holloszy JO, Kelly DP: A role for the transcriptional coactivator PGC-1alpha in muscle refueling. $J$ Biol Chem 2007, 282:36642-36651.

41. Megeney LA, Kablar B, Garrett K, Anderson JE, Rudnicki MA: MyoD is required for myogenic stem cell function in adult skeletal muscle. Genes Dev 1996, 10:1173-1183.

42. Rando TA, Blau HM: Primary mouse myoblast purification, characterization, and transplantation for cell-mediated gene therapy. J Cell Biol 1994, 125:1275-1287.

43. St-Pierre J: Bioenergetic analysis of peroxisome proliferator-activated receptor coactivators 1alpha and 1beta (PGC-1alpha and PGC-1beta) in muscle cells. J Biol Chem 2003, 278:26597-26603.

44. Liu DW, Westerfield M: The formation of terminal fields in the absence of competitive interactions among primary motoneurons in the zebrafish. J Neurosci 1990, 10:3947-3959.

45. Golde WT, Gollobin P, Rodriguez LL: A rapid, simple, and humane method for submandibular bleeding of mice using a lancet. Lab Anim (NY) 2005, 34:39-43.

46. Arany ZP: High-Throughput Quantitative Real-Time PCR. Current Protocols in Human Genetics 2008, 58:11.10.1-11.10.11.

47. Guevel L, Lavoie JR, Perez-Iratxeta C, Rouger K, Dubreil L, Feron M, Talon S, Brand M, Megeney LA: Quantitative proteomic analysis of dystrophic Dog muscle. J Proteome Res 2011, 10:2465-2478.

48. Briguet A, Courdier-Fruh I, Foster M, Meier T, Magyar JP: Histological parameters for the quantitative assessment of muscular dystrophy in the mdx-mouse. Biochem Pharmacol 2004, 14:675-682.

49. Brussee $V$, Tardif F, Tremblay JP: Muscle fibers of $\mathrm{mdx}$ mice are more vulnerable to exercise than those of normal mice. Neuromuscul Disord 1997, 7:487-492.

50. Zhang Y, Duan D: Novel mini-dystrophin gene dual adeno-associated virus vectors restore neuronal nitric oxide synthase expression at the sarcolemma. Hum Gene Ther 2012, 23:98-103. 
51. Inmaculada V, Álvarez-Barrientosb A, Arzab E, Lamas S, Monsalvea M: PGC-1 a regulates the mitochondrial antioxidant defense system in vascular endothelial cells. Cardiovasc Res 2005, 66:562-573.

52. St-Pierre J, Drori S, Uldry M, Silvaggi JM, Rhee J, Jäger S, Handschin C, Zheng K, Lin J, Yang W, Simon DK, Bachoo R, Spiegelman BM: Suppression of reactive oxygen species and neurodegeneration by the PGC-1 transcriptional coactivators. Cell 2006, 127:397-408.

53. Austin S, St-Pierre J: PGC1a and mitochondrial metabolism - emerging concepts and relevance in ageing and neurodegenerative disorders. J Cell Sci 2012, 125:4963-4971.

54. Bornman L, Rossouw H, Gericke GS, Polla BS: Effects of iron deprivation on the pathology and stress protein expression in murine X-linked muscular dystrophy. Biochem Pharmacol 1998, 56:751-757.

55. Buetler TM, Renard M, Offord EA, Schneider H, Ruegg UT: Green tea extract decreases muscle necrosis in $\mathrm{mdx}$ mice and protects against reactive oxygen species. Am J Clin Nutr 2002, 75:749-753.

56. Rando TA, Disatnik M-H, Yu Y, Franco A: Muscle cells from mdx mice have an increased susceptibility to oxidative stress. Biochem Pharmacol 1998, 8:14-21.

57. Whitehead NP, Yeung EW, Allen DG: Muscle damage in mdx (dystrophic) mice: role of calcium and reactive oxygen species. Clin Exp Pharmacol Physiol 2006, 33:657-662

58. Godin R, Daussin F, Matecki S, Li T, Petrof BJ, Burelle Y: Peroxisome proliferator-activated receptor coactivator $1-a$ gene transfer restores mitochondrial biomass and improves mitochondrial calcium handling in post-necrotic mdx mouse skeletal muscle. J Physiol 2012, 590:5487-5502.

59. Webster C, Silberstein L, Hays AP, Blau HM: Fast muscle fibers are preferentially affected in Duchenne muscular dystrophy. Cell 1988, 52:503-513.

60. Chakkalakal JV, Miura P, Belanger G, Michel RN, Jasmin BJ: Modulation of utrophin A mRNA stability in fast versus slow muscles via an AU-rich element and calcineurin signaling. Nucleic Acids Res 2007, 36:826-838.

61. Pastoret $C$, Sebille: $\mathrm{mdx}$ mice show progressive weakness and muscle deterioration with age. J Neurol Sci 1995, 129:97-105.

62. Sacco A, Mourkioti F, Tran R, Choi J, Llewellyn M, Kraft P, Shkreli M, Delp S, Pomerantz JH, Artandi SE, Blau HM: Short telomeres and stem cell exhaustion model Duchenne muscular dystrophy in $\mathrm{mdx} / \mathrm{mTR}$ mice. Cell 2010, 143:1059-1071

63. Hollinger K, Gardan-Salmon D, Santana C: Rescue of dystrophic skeletal muscle by PGC-1a involves restored expression of dystrophin associated protein complex components and satellite cell signaling. Am J Physiol Regul Integr Comp Physiol 2013, 305:R13-R23.

64. Miura P, Chakkalakal JV, Boudreault L, Belanger G, Hebert RL, Renaud JM, Jasmin BJ: Pharmacological activation of PPARbeta/delta stimulates utrophin $A$ expression in skeletal muscle fibers and restores sarcolemmal integrity in mature mdx mice. Hum Mol Genet 2009, 18:4640-4649.

65. Hori YS, Kuno A, Hosoda R, Tanno M, Miura T, Shimamoto K, Horio Y: Resveratrol ameliorates muscular pathology in the dystrophic $\mathrm{mdx}$ mouse, a model for Duchenne muscular dystrophy. J Pharmacol Exp Ther 2011, 338:784-794.

66. Jahnke VE, Van Der Meulen JH, Johnston HK, Ghimbovschi S, Partridge T, Hoffman EP, Nagaraju K: Metabolic remodeling agents show beneficial effects in the dystrophin-deficient mdx mouse model. Skelet Muscle 2012, 2:16.

doi:10.1186/2044-5040-4-2

Cite this article as: Chan et al:: Post-natal induction of PGC-1a protects against severe muscle dystrophy independently of utrophin. Skeletal Muscle 2014 4:2.

\section{Submit your next manuscript to BioMed Central and take full advantage of:}

- Convenient online submission

- Thorough peer review

- No space constraints or color figure charges

- Immediate publication on acceptance

- Inclusion in PubMed, CAS, Scopus and Google Scholar

- Research which is freely available for redistribution

Submit your manuscript at www.biomedcentral.com/submit
C Biomed Central 